\title{
Studies on the Mode of Action of Antlermicin A on Bacillus subtilis
}

\author{
Hachiro Kamada, ${ }^{* *}$ Kazuo IzaKI, Kiyoshi Isono* \\ and Hajime TAKAHASHI \\ Department of Agricultural Chemistry, Faculty of Agriculture, \\ Tohoku University, Sendai 980, Japan \\ *Antibiotics Laboratory, The Institute of Physical and \\ Chemical Research, Wako-shi, Saitama 351, Japan
}

Received August 8, 1983

\begin{abstract}
Antlermicin A is a new antitumor antibiotic which inhibits growth of Bacillus subtilis strongly. As uridine incorporation into the TCA insoluble fraction of Bacillus subtilis was inhibited severely, it was suggested that antlermicin A inhibited RNA synthesis. Both syntheses of uridine and uridine nucleotides were not inhibited and furthermore, accumulation of uridine nucleotides was observed in the presence of antlermicin A. The RNA polymerase reaction in a cell-free system was inhibited significantly only at a high concentration of this antibiotic.
\end{abstract}

New antitumor antibiotics designated as antlermicin A and tetrocarcin A were isolated from the culture filtrate of Micromonospora chalcea and characterized independently in two laboratories ${ }^{1,2)}$ and they were found to be identical. ${ }^{2}$ Structurally related compounds to antlermicin A have also been isolated and characterized. ${ }^{2 \sim 5)}$ These antibiotics showed strong growth-inhibitory activities against Bacillus subtilis, while other Gram-positive bacteria were less sensitive and Gram-negative bacteria were fully resistant to these antibiotics. Tetrocarcin A was found to inhibit strongly uracil incorporation into RNA in $B$. subtilis. ${ }^{5}$ ) On the other hand, protein and DNA syntheses were found to be more severely inhibited than RNA synthesis by tetrocarcin A in $\mathrm{P} 388$ leukemia cells. ${ }^{6}{ }^{6}$ Tetrocarcin A did not inhibit RNA polymerase of $B$. subtilis significantly and its destructive effect on the cell membrane structure was suggested. ${ }^{7)}$ The present paper describes studies on the mode of action of antlermicin A on B. subtilis.

\section{MATERIALS AND METHODS}

Bacterial strains. B. subtilis strain $111\left(\mathrm{leu}^{-}\right)$and $B$. subtilis strain $168 \mathrm{TI}\left(\right.$ thy $^{-}, \operatorname{trp}^{-}$) were kindly provided by
Dr. H. Saito, the Institute of Applied Microbiology, University of Tokyo. B. subtilis 111 was used throughout this work except in the thymine incorporation experiment, for which B. subtilis 168 TI was used.

Medium. Nutrient broth and nutrient agar were used for most experiments. Spizizen minimal medium ${ }^{8)}$ was used to determine the effect of antlermicin A on the syntheses of nucleosides and nucleotides.

Cultural conditions. The minimal inhibitory concentration of antlermicin A was measured by the nutrient agar plate culture method. The effect of antlermicin A was examined after incubation at $37^{\circ} \mathrm{C}$ for $20 \mathrm{hr}$. For liquid cultures, bacteria were grown in $100 \mathrm{ml}$ of nutrient broth in a $500 \mathrm{ml}$ shaking flask with shaking at $30^{\circ} \mathrm{C}$, and the absorbancy at $660 \mathrm{~nm}$ was measured with a Hitachi FPW4 photoelectric colorimeter.

Measurement of incorporation of labeled precursors into macromolecules. Cells of B. subtilis 111 were grown to the logarithmic phase in nutrient broth. Antlermicin A and labeled substrate were added to a $10 \mathrm{ml}$ culture in an $100 \mathrm{ml}$ test tube. Various concentrations of antlermicin A dissolved in methylcellosolve were added to the culture. At appropriate time intervals, $1.0 \mathrm{ml}$ of the culture was withdrawn and mixed with $1.0 \mathrm{ml}$ of $10 \%$ trichloroacetic acid (TCA). The precipitates were collected on a TM-2 filter (Toyo Kagaku Sangyo Co., Ltd., Tokyo) and washed three times with $2.0 \mathrm{ml}$ of cold $5 \%$ TCA. The filter was incubated in $1.0 \mathrm{ml}$ of $5 \%$ sodium dodecyl sulfate in a counting vial at $37^{\circ} \mathrm{C}$ overnight. Radioactivity was measured with an Aloka liquid scintillation spectrometer

** Present address: Department of Nutrition, National Institute of Animal Industry, Ibaragi 305, Japan. 
model LSC 900 (Aloka Co., Ltd., Tokyo) using a scintillation fluid of toluene-Nonione ${ }^{9)}$ from which POPOP was omitted.

Effect of antlermicin $A$ on the synthesis of nucleotides. Cells of $B$. subtilis 111 were grown to the logarithmic phase in the minimal medium $\left(A_{660}=0.122\right)$. Antlermicin $\mathrm{A}$ ( $20 \mu \mathrm{g} / \mathrm{ml}$, dissolved in $0.1 \%$ dimethyl sulfoxide) and ${ }^{3} \mathrm{H}$ labeled uridine $(1 \mu \mathrm{Ci}, 42 \mathrm{Ci} / \mathrm{mmol})$ were added to a $10 \mathrm{ml}$ culture in an $100 \mathrm{ml}$ test tube. At appropriate time intervals, $1.0 \mathrm{ml}$ of the mixture was withdrawn and mixed with $1.0 \mathrm{ml}$ of $10 \%$ TCA. After centrifugation, the supernatants were extracted three times with $1.0 \mathrm{ml}$ of diethylether to remove TCA and then lyophilized. The dried samples were dissolved in water and unlabeled uracil, uridine, UMP, UDP and UTP were added as carriers. These samples were spotted on a filter paper (Whatman $3 \mathrm{MM}$ ) and subjected to paper chromatography with a solvent system of ethanol-1 $\mathrm{M}$ ammonium acetate $(\mathrm{pH} 7.0), 7.5: 3$. After drying, the spots were located from their UV light absorption, and then cut out and eluted with water in vials. The radioactivities were measured as described above.

Purification of RNA polymerase. RNA polymerase was purified from vegetative cells of $B$. subtilis 111 , which were grown in a modified Schaeffer medium, ${ }^{10}$ ) by the method of Nakayama et al. ${ }^{11)}$ Cells were disrupted with a French pressure cell $\left(500 \sim 600 \mathrm{~kg} / \mathrm{cm}^{2}\right)$ three times. After centrifugation, hemoglobin Sepharose (an affinity substrate for protease) ${ }^{12)}$ was added to remove protease. After centrifugation, phase extractions were performed on the supernatant by the method of Babinet. ${ }^{13}$ ) The final dextran phase was dialyzed and subjected to DEAE cellulose column chromatography and DNA cellulose column chromatography. The purified enzyme was stored at a final concentration of $50 \%$ glycerol at $-20^{\circ} \mathrm{C}$.

RNA polymerase assay. The reaction mixture contained $40 \mathrm{~mm}$ Tris- $\mathrm{HCl}$ ( $\mathrm{pH} 7.9$ ), $0.1 \mathrm{~mm}$ dithiothreitol, $0.2 \mathrm{~mm}$ each of ATP, UTP, GTP and CTP, $0.2 \mu \mathrm{Ci}\left({ }^{3} \mathrm{H}\right)$ UTP $(25$ $\mathrm{Ci} / \mathrm{mmol}$ ), $3 \mathrm{~mm} \mathrm{MnCl}_{2}$ or $\mathrm{MgCl}_{2}, 0.15 \mathrm{M} \mathrm{KCl}, 0.1 \mathrm{~mm}$ EDTA, various concentrations of antlermicin $\mathrm{A}$ in dimethylsulfoxide and purified enzyme (400-fold purified preparation over the crude extract from $B$. subtilis $111,{ }^{11)} 6 \mu \mathrm{g}$ ) in a total volume of $0.25 \mathrm{ml}$. After preincubation for $2 \mathrm{~min}$, the reaction was initiated by the addition of DNA template, either $2 \mu \mathrm{g}$ of poly (dA-dT) or $7 \mu \mathrm{g}$ of B. subtilis 111 DNA prepared by the method of Saito and Miura. ${ }^{14)}$ After incubation for $10 \mathrm{~min}$, radioactivity incorporated into the TCA insoluble fraction was measured. ${ }^{15)}$

Chemicals. Antlermicin A used was isolated as previously described. ${ }^{1)}$ (methyl- $\left.{ }^{3} \mathrm{H}\right)$ Thymine $(33 \mathrm{Ci} / \mathrm{mmol})$, $\left(5,6-{ }^{3} \mathrm{H}\right)$ uridine $(42 \mathrm{Ci} / \mathrm{mmol}), \mathrm{L}-\left(\mathrm{U}-{ }^{14} \mathrm{C}\right)$ amino acid mixture $(58 \mathrm{mCi} / \mathrm{matom}),\left(2-{ }^{3} \mathrm{H}\right)$ glycerol $(500 \mathrm{mCi} / \mathrm{mmol})$ and $\left(5-{ }^{3} \mathrm{H}\right)$ UTP $(25 \mathrm{Ci} / \mathrm{mmol})$ were purchased from the
'Radiochemical Centre, Amersham. D- $\left(1-{ }^{14} \mathrm{C}\right)$ Glucosamine $(45 \mathrm{mCi} / \mathrm{mmol})$ was a product of Daiichi Pure Chemical Co., Tokyo. All other chemicals were purchased from commercial sources.

\section{RESULTS}

\section{Effect of antlermicin $A$ on growth}

The minimal inhibitory concentrations of antlermicin A for B. subtilis 111 and B. subtilis $168 \mathrm{TI}$ were $0.2 \mu \mathrm{g} / \mathrm{ml}$ and $0.5 \mu \mathrm{g} / \mathrm{ml}$, respectively. The effect of antlermicin A on growth of $B$. subtilis was also examined in a liquid culture. Two different inoculum sizes were used. As shown in Fig. 1, an inhibitory effect was apparent at the concentration of 2 $\mu \mathrm{g} / \mathrm{ml}$ of antlermicin A, when the inoculumn size was small. When the inoculum size was increased about 5 times, the inhibitory effect of antlermicin A was not so significant compared with that of the smaller inoculum size.

\section{Effect of antlermicin $A$ on the syntheses of macromolecules}

The effects of antlermicin A on the syntheses of DNA, RNA, protein and lipid and incorporation of ${ }^{14} \mathrm{C}$-glucosamine into polymers in growing cells of $B$. subtilis were investigated. As shown in Fig. 2, RNA synthesis was immediately and most severely inhibited and only slight inhibition was observed of the syntheses

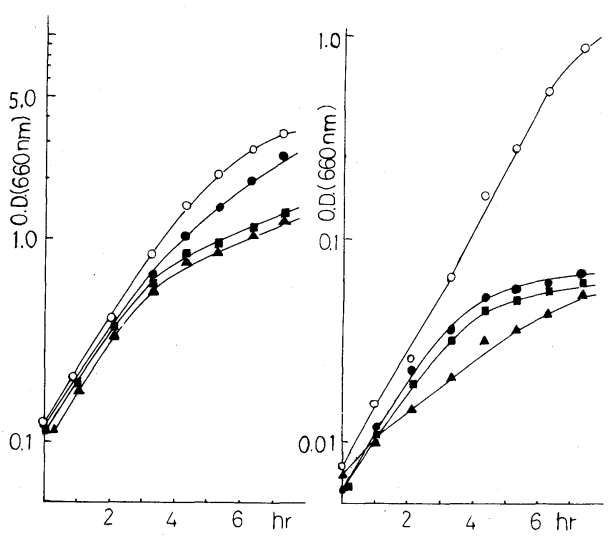

FIG. 1. Effect of Antlermicin A on Growth.

$\bigcirc,+0.1 \%$ methylcellosolve only;,$+0.2 \mu \mathrm{g} / \mathrm{ml}$ antler$\operatorname{micin} \mathrm{A} ; \boldsymbol{\Delta},+2.0 \mu \mathrm{g} / \mathrm{ml}$ antlermicin $\mathrm{A} ; \mathbf{\square},+20 \mu \mathrm{g} / \mathrm{ml}$ antlermicin $\mathbf{A}$. 

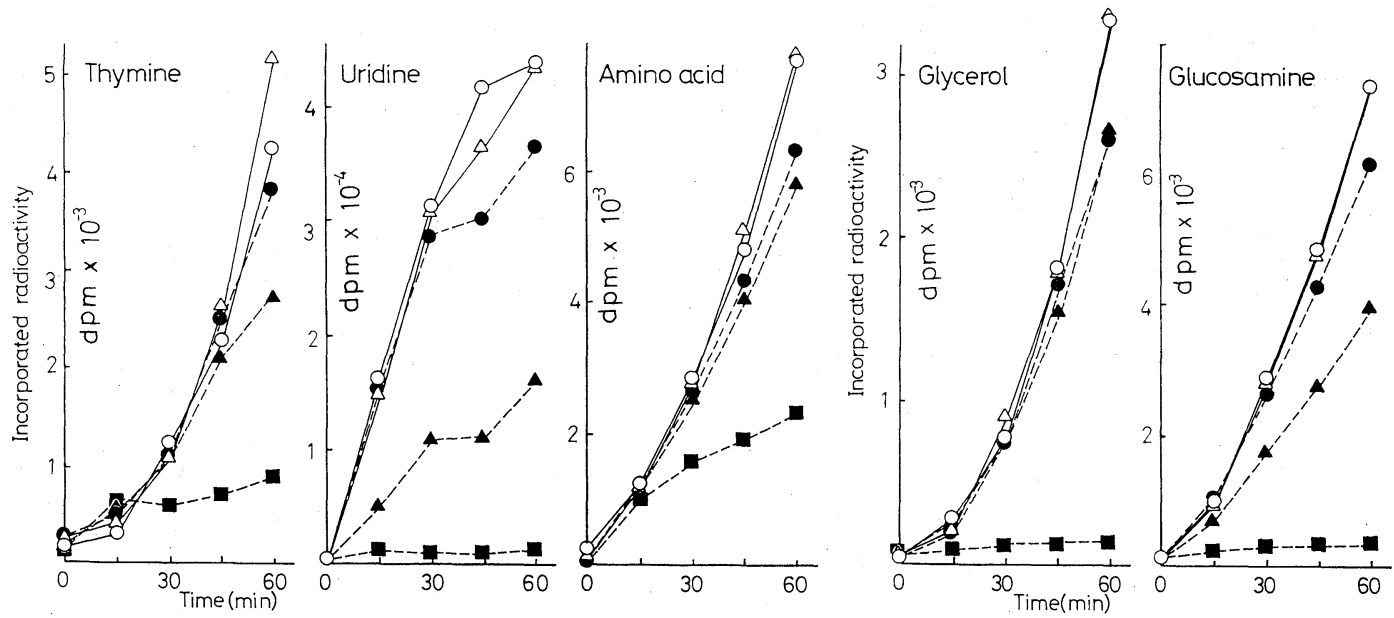

FIG. 2. Effect of Antlermicin A on Incorporation of Labeled Precursors into DNA, RNA, Protein and Lipid and That of ${ }^{14} \mathrm{C}$-Glucosamine into Cell Polymers.

$\bigcirc$, control; $\triangle,+0.1 \%$ methylcellosolve only;

$+10 \mu \mathrm{g} / \mathrm{ml}$ antlermicin $\mathrm{A}$

$\mathbf{\Delta},+20 \mu \mathrm{g} / \mathrm{ml}$ antlermicin $\mathrm{A}$;

口, $+40 \mu \mathrm{g} / \mathrm{ml}$ antlermicin A.

of lipid, DNA and protein at $20 \mu \mathrm{g} / \mathrm{ml}$, while severe inhibition was observed of the syntheses of all macromolecules at $40 \mu \mathrm{g} / \mathrm{ml}$. Although glucosamine incorporation into polymers was significantly inhibited by this antibiotic, RNA synthesis is more sensitive than the former.

Effect of antlermicin $A$ on the syntheses of nucleosides and nucleotides

It is possible to consider that the synthesis of nucleosides was inhibited by antlermicin A. This possibility, however, is not likely since the inhibition of growth in the presence of antlermicin $\mathrm{A}$ is not relieved by the addition of four nucleosides [uridine, adenosine, cytidine and guanosine $(1 \mu \mathrm{g} / \mathrm{ml}$ or $10 \mu \mathrm{g} / \mathrm{ml}$ or $100 \mu \mathrm{g} / \mathrm{ml})$ ] to an inhibited culture (data not shown). We checked whether or not the phosphorylation of uridine was inhibited by antlermicin A by analyzing the TCA soluble fraction of cells pre-labeled with ${ }^{3} \mathrm{H}$-uridine after treatment with or without antlermicin A. Since UDP and UTP were not well separated in this experiment, these two fractions were combined and counted together. As shown in Fig. 3, the radioactivities of the UMP and UDP-UTP fractions were increased significantly in the presence of antlermicin A. These results sug-

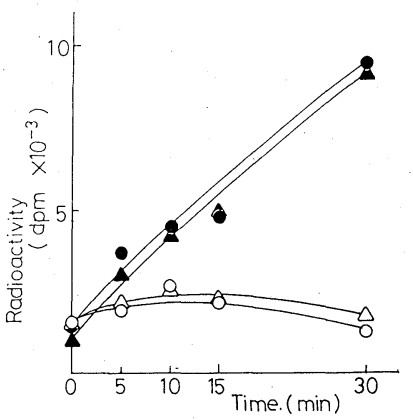

FIG. 3. Accumulation of Uridine Nucleotides in the Presence of Antlermicin A.

${ }^{3} \mathrm{H}$-labeled uridine plus dimethyl sulfoxide (final conc., $0.1 \%$ ) or ${ }^{3} \mathrm{H}$-labeled uridine plus antlermicin A (final conc., $20 \mu \mathrm{g} / \mathrm{ml}$ ), dissolved in dimethyl sulfoxide (final conc., $0.1 \%$ ) were added to the growing culture and the mixture incubated at $30^{\circ} \mathrm{C}$ for $30 \mathrm{~min}$. At various incubation times, an aliquot of the culture was withdrawn and the amount of labeled uridine nucleotide in the cells was determined. Radioactivities of uridine nucleotides in the TCA soluble fraction of cells versus time were plotted. $\bigcirc$, UMP from cells incubated with dimethyl sulfoxide $0.1 \%$ only; $\triangle$, UDP + UTP from cells incubated with dimethyl sulfoxide $0.1 \%$ only; O, UMP from cells incubated with $20 \mu \mathrm{g} / \mathrm{ml}$ antlermicin A and $0.1 \%$ dimethyl sulfoxide; $\boldsymbol{\Delta}$, UDP + UTP from cells incubated with $20 \mu \mathrm{g} / \mathrm{ml}$ antlermicin $\mathrm{A}$ and $0.1 \%$ dimethyl sulfoxide.

gested that the phosphorylation of uridine was not inhibited by antlermicin $\mathrm{A}$ and the accumulation of uridine nucleotides was caused by 
Table I. Inhibition of RNA Polymerase by Antlermicin A under Various Conditions

\begin{tabular}{|c|c|c|c|c|c|c|c|c|}
\hline \multirow[b]{5}{*}{$\begin{array}{c}\text { Antlermicin A } \\
\text { concentration } \\
(\mu \mathrm{g} / \mathrm{ml})\end{array}$} & \multicolumn{8}{|c|}{ Metal ions } \\
\hline & \multicolumn{4}{|c|}{$\mathrm{Mn}^{2+}$} & \multicolumn{4}{|c|}{$\mathrm{Mg}^{2+}$} \\
\hline & \multicolumn{8}{|c|}{ Template } \\
\hline & \multicolumn{2}{|c|}{ Poly(dA-dT) } & \multicolumn{2}{|c|}{ B. subtilis DNA } & \multicolumn{2}{|c|}{ Poly(dA-dT) } & \multicolumn{2}{|c|}{ B. subtilis DNA } \\
\hline & $(\mathrm{dpm})$ & $(\%)^{a}$ & $(\mathrm{dpm})$ & $(\%)$ & $(\mathrm{dpm})$ & $(\%)$ & $(\mathrm{dpm})$ & $(\%)$ \\
\hline 0 & 7,200 & & 4,070 & & 6,150 & & 4,040 & \\
\hline 20 & 7,150 & 1 & 4,450 & 0 & 6,270 & 0 & 4,190 & 0 \\
\hline 50 & 7,340 & 0 & 3,760 & 8 & 6,350 & 0 & 3,350 & 17 \\
\hline 100 & 5,990 & 17 & 3,660 & 10 & 4,850 & 21 & 1,730 & 57 \\
\hline 200 & 3,240 & 55 & 3,120 & 23 & 2,030 & 67 & 670 & 83 \\
\hline
\end{tabular}

a Inhibition percent.

the inhibition of the RNA polymerase reaction.

\section{Effect of antlermicin $A$ on the RNA polymerase reaction}

The experiment described above indicated that antlermicin A inhibited RNA synthesis more severely compared to other macromolecular syntheses. In order to examine the effect of antlermicin A on the RNA polymerase reaction, we prepared DNA-dependent RNA polymerase and examined the effect of antlermicin A on the RNA polymerase reaction. As shown in Table I, antlermicin A inhibited the RNA polymerase reaction only at high concentrations (100 to $200 \mu \mathrm{g} / \mathrm{ml}$ ). Although we used $\mathrm{Mn}^{2+}$ or $\mathrm{Mg}^{2+}$ ions as a divalent cation, and $B$. subtilis native DNA or poly (dA-dT) as a template, no significant differences in the degree of inhibition were observed under these conditions. Varying concentrations $(30 \mu \mathrm{M}$ to $3 \mathrm{~mm}$ ) of $\mathrm{Mn}^{2+}$ or $\mathrm{Mg}^{2+}$ did not affect the degree of inhibition significantly (data not shown). The degree of inhibition was also not enhanced when the polymerase reaction was performed at $\mathrm{pH} 7.0$ or antlermicin $\mathrm{A}$ was initially preincubated with DNA and then the enzyme was added later (data not shown). When the enzyme was preincubated with antlermicin A longer prior to the addition of
Table II. Effect of Preincubation time on the Degree of InHIBITION OF RNA Polymerase BY ANTLERMicin A

The reaction mixture from which template DNA was omitted was preincubated for various times, and the reaction was started by the addition of the template, poly(dA-dT). $\mathrm{Mn}^{2+}$ was used as divalent cation.

\begin{tabular}{cccc}
\hline $\begin{array}{c}\text { Preincubation } \\
\text { time } \\
(\mathrm{min})\end{array}$ & $\begin{array}{c}\text { Antlermicin A } \\
\text { concentration } \\
(\mu \mathrm{g} / \mathrm{ml})\end{array}$ & $(\mathrm{dpm})$ & $\begin{array}{c}\text { Inhibition } \\
(\%)\end{array}$ \\
\hline 5 & 0 & 3,980 & \\
& 50 & 3,170 & 20 \\
& 100 & 1,680 & 58 \\
10 & 0 & 3,180 & \\
& 50 & 2,930 & 8 \\
& 100 & 1,040 & 67 \\
20 & 0 & 2,280 & \\
& 50 & 1,550 & 32 \\
& 100 & 300 & 87 \\
\hline
\end{tabular}

DNA template, the degree of inhibition seemed to become higher as shown in Table II, although the enzyme activity decreased considerably during prolonged preincubation.

\section{Effect of antlermicin $A$ on cell envelopes}

Since glucosamine incorporation was significantly inhibited by antlermicin A, the synthesis of cell envelopes might be affected by antlermicin A. This would affect the cell membrane and leakage of cellular components 
from the cells might be expected. The leakage of cell materials labeled with ${ }^{14} \mathrm{C}$-amino acids or ${ }^{3} \mathrm{H}$-uridine was not stimulated by antlermicin A (data not shown). These data indicate that antlermicin A did not affect the cell wall and membrane so as to permit the leakage of cell materials, at least, under the present conditions.

\section{DISCUSSION}

The inhibitory effect of antlermicin A on growth of B. subtilis seems to be markedly influenced by the growth conditions. Twotenth $\mu \mathrm{g} / \mathrm{ml}$ of antlermicin $\mathrm{A}$, which is equal to the minimal inhibitory concentration value determined by the plate culture method, had no growth inhibitory effect when the bacteria were cultured in nutrient broth liquid medium as shown in Fig. 1. The inoculum size also greatly influenced the inhibitory effect of antlermicin A. We have no clear explanation for these phenomena at present. The effect of antlermicin A on macromolecular syntheses indicated that RNA synthesis was most sensitive and glucosamine incorporation was next. We first assumed that antlermicin A inhibited RNA synthesis at the step of either RNA polymerization or synthesis of nucleosides or nucleotides. The synthesis of nucleosides is not likely to be inhibited by antlermicin A, since the inhibitory effect of antlermicin $\mathrm{A}$ on growth was not counteracted by the addition of nucleosides. The fact that the synthesis of uridine nucleotides was not inhibited but rather stimulated in the presence of antlermicin A also suggested that the synthesis of uridine nucleotides is not a target reaction and accumulation of uridine nucleotides might be explained if the RNA polymerase reaction is inhibited by this antibiotic. We then examined the effect of antlermicin A on the RNA polymerase reaction in vitro. As shown in Table I, antlermicin A inhibited RNA polymerase only at high concentrations. The degree of inhibition was not significantly influenced by the nature of the template, concentration of $\mathrm{Mg}^{2+}$ or $\mathrm{Mn}^{2+}$ ions or $\mathrm{pH}$.

The concentration of antlermicin A required to inhibit the RNA polymerase reaction in vitro seems to be too high to explain the inhibitory action of this antibiotic in vivo. The difference between the inhibitory concentration for the polymerase reaction in vitro and that for growth can be explained by the following considerations. First, antlermicin A might be concentrated in vivo to a concentration high enough to inhibit RNA polymerase. Second, antlermicin A might be activated in the cells to a more toxic form and factors needed for this activation are lacking in the mixture for the RNA polymerase reaction. Glucosamine incorporation into the TCA-insoluble fraction was also inhibited significantly. Our experiment showed that antlermicin A did not affect the cell wall and membrane so as to permit the leakage of cell materials, at least under the conditions used. This is different from the results obtained by Tamaoki et al. ${ }^{7)} \mathrm{We}$ are interested in whether antlermicin A inhibits in vitro peptidoglycan synthesis. Because of the difficulty in obtaining an active preparation for in vitro peptidoglycan synthesis from cells of $B$. subtilis, we preliminarily examined the effect of antlermicin A on in vitro peptidoglycan synthesis in E. coli. Approximately $400 \mu \mathrm{g} / \mathrm{ml}$ of antlermicin A was required to inhibit the synthesis of peptidoglycan by $50 \%$.

Acknowledgment. This investigation was supported by a Grant-in-Aid for Scientific Research (to K. I., 58560097) from the Ministry of Education, Science and Culture of Japan.

\section{REFERENCES}

1) K. Kobinata, M. Uramoto, T. Mizuno and K. Isono, J. Antibiot., 33, 244 (1980).

2) F. Tomita, T. Tamaoki, K. Shirahata, M. Kasai, M. Morimoto, S. Ohkubo, K. Mineura and S. Ishii, $J$. Antibiot., 33, 668 (1980).

3) K. Kobinata, M. Uramoto, T. Mizuno and K. Isono, J. Antibiot., 33, 772 (1980).

4) F. Tomita and T. Tamaoki, J. Antibiot., 33, 940 (1980).

5) T. Tamaoki, M. Kasai, K. Shirahata, S. Ohkubo, M. Morimoto, K. Mineura, S. Ishii and F. Tomita, J. Antibiot., 33, 946 (1980). 
6) M. Morimoto, M. Fukui, S. Ohkubo, T. Tamaoki and F. Tomita, J. Antibiot., 35, 1033 (1982).

7) T. Tamaoki, F. Tomita, F. Kawamura and H. Saito, Agric. Biol. Chem., 47, 59 (1983).

8) C. Anagnostopoulos and J. Spizizen, J. Bacteriol., 81, 741 (1961).

9) M. Kawakami and K. Shimura, Radioisotopes, 23, 81 (1974).

10) P. Schaeffer, J. Millet and J. Aubert, Proc. Natl. Acad. Sci. U.S.A., 54, 704 (1965).
11) T. Nakayama, V. Williamson, K. Burtis and R. H. Doi, E. J. Biochem., 88, 155 (1978).

12) K. G. Chura and W. Bushuk, Biochem. Biophys. Res. Commun., 37, 545 (1969).

13) C. Babinet, Biochem. Biophys. Res. Commun., 26, 639 (1967).

14) H. Saito and K. Miura, Biochim. Biophys. Acta, 72, 619 (1963).

15) J.-E. Ikeda and H. Saito, J. Biochem., 80, 743 (1976). 